\title{
Feasibility and performance of high-rate psychrophilic dry anaerobic digestion of high solids content dairy manure
}

\author{
Noori M. Cata Saady ${ }^{1}$ Daniel I. Massé ${ }^{1}$
}

Received: 14 September 2015/Accepted: 5 January 2016/Published online: 26 January 2016

(C) The Author(s) 2016. This article is published with open access at Springerlink.com

\begin{abstract}
Purposes The main purpose of the R\&D was to develop a novel high-rate psychrophilic dry anaerobic digestion (PDAD) for processing a mixture of cow feces and wheat straw (CFWS) in sequencing batch bioreactor (SBR) operated at high organic loading rate (OLR). The main research question was to assess the feasibility of operating the PDAD-SBR at OLR of 9.0 and $10.0 \mathrm{~g} \mathrm{TCOD} \mathrm{kg}^{-1}$ inoculum day ${ }^{-1}$.

Methods Two pairs of $40 \mathrm{~L}$ duplicate bioreactors located in a temperature-controlled room $\left(20^{\circ} \mathrm{C}\right)$ were operated as sequencing batch reactors (SBRs) and were fed CFWS (27\% total solids) at OLRs of 9.0 and $10.0 \mathrm{~g}_{\text {TCOD kg}}^{-1}$ inoculum day ${ }^{-1}$ during three successive treatment cycles of 21 days each. The biogas production, biogas composition, volatile fatty acids, and volatile solids were monitored to assess the performance of the PDAD-SBRs.

Results The PDAD process fed with cow feces and wheat straw (TS of $27 \%$ ) at OLR 9.0 and $10.0 \mathrm{~g}^{\mathrm{TCOD} \mathrm{kg}}{ }^{-1}$ inoculum day ${ }^{-1}\left(6.53 \pm 0.06\right.$ and $7.27 \pm 0.12 \mathrm{~g} \mathrm{VS} \mathrm{kg}^{-1}$ inoculum day ${ }^{-1}$ ) resulted in average specific methane yields (SMYs) of $134.0 \pm 7.7,136.4 \pm 4.9{ }_{\mathrm{N}} \mathrm{L} \mathrm{CH}_{4} \mathrm{~kg}^{-1} \mathrm{VS}$ fed, respectively, with an average volatile solids removal of $35 \%$ at the ends of treatment cycles ( 21 days).

Conclusions This study reports for the first time successful operation of psychrophilic $\left(20{ }^{\circ} \mathrm{C}\right)$ dry anaerobic digestion
\end{abstract}

Electronic supplementary material The online version of this article (doi:10.1007/s40093-016-0115-9) contains supplementary material, which is available to authorized users.

\section{Daniel I. Massé}

Daniel.masse@agr.gc.ca

1 Dairy and Swine Research and Development Centre, Agriculture and Agri-Food Canada, Sherbrooke, QC J1M 0C8, Canada
(PDAD) of cow feces with wheat straw (CFWS) at $27 \%$ total solids and OLR of 9.0 and $10.0 \mathrm{~g}$ TCOD kg$~^{-1}$ inoculum day $^{-1}$ in relatively short treatment cycle length (21 days).

Keywords Cow manure - Dry anaerobic digestion · High-solids · High-rate $\cdot$ Psychrophilic $\cdot$ Wheat straw

\section{Introduction}

Stabilization of biodegradable organics in solid manure from livestock industry has been a challenge because conventional wet anaerobic digestion (WAD; Table 1) requires dilute influent which could be pumped in and out of the digester, mixed, and heated, thus digesters of large volume would be required. So far, conventional anaerobic digestion (AD) of cattle manure has been ineffective because of increased energy input for mixing and heating. In addition, the large volumes of digesters decrease the specific methane yield (SMY) per unit volume of digester. Theoretically, increasing the biodegradable organics content of the substrate increases the specific volumetric methane yield. Solid cattle manure (total solids $=25 \%$; Demirer and Chen 2008) is richer in its biodegradable organics than dilute slurries $(\mathrm{TS}=5 \%)$. Therefore, developing a static dry anaerobic digestion (DAD; TS $>15 \%$ ) to replace WAD would increase the specific volumetric methane yield and eliminate energy expenditure for mixing. Based on 30 days batch anaerobic digestion of lignocellulosic substrates, Brown et al. (2012) found that volumetric productivity of DAD (18\% TS) is 2- to 7-times greater than that of WAD (5\% TS). Moreover, if psychrophilic rather than mesophilic or thermophilic operation is adopted less energy input for heating would be required and the net energy recovery would be increased. Schäfer et al. (2006) stated that DAD is 
Table 1 Nomenclature

\begin{tabular}{|c|c|}
\hline $\mathrm{AD}$ & Anaerobic digestion \\
\hline $\mathrm{ADF}$ & Acid detergent fiber \\
\hline $\mathrm{ADL}$ & Acid detergent lignin \\
\hline APHA & American Public Health Association \\
\hline CFWS & Cow feces and wheat straw mixture \\
\hline $\mathrm{CH}_{4}$ & Methane \\
\hline $\mathrm{CO}_{2}$ & Carbon dioxide \\
\hline DAD & Dry anaerobic digestion \\
\hline DSRDC & $\begin{array}{l}\text { Dairy and Swine Research and Development Centre, } \\
\text { Agriculture and Agri-Food Canada, Sherbrooke, } \\
\text { Quebec }\end{array}$ \\
\hline GC & Gas chromatograph \\
\hline $\mathrm{H}_{2} \mathrm{~S}$ & Hydrogen sulfide \\
\hline HRT & Hydraulic retention time \\
\hline ISM & Inoculum-substrate mixture \\
\hline ISR & VS-based inoculum-to-substrate ratio \\
\hline $\mathrm{N}_{2}$ & Nitrogen gas \\
\hline $\mathrm{NDF}$ & Detergent fiber \\
\hline${ }_{\mathrm{N}} \mathrm{L}$ & $\begin{array}{l}\text { Normalized liter (at standard temperature and pressure; } \\
273 \mathrm{~K} \text { and } 101.3 \mathrm{kPa} \text { ) }\end{array}$ \\
\hline OLR & Organic loading rate \\
\hline PDAD & Psychrophilic dry anaerobic digestion \\
\hline $\begin{array}{l}\text { PDAD- } \\
\text { SBR }\end{array}$ & $\begin{array}{l}\text { Psychrophilic dry anaerobic digestion—sequence batch } \\
\text { reactor }\end{array}$ \\
\hline PSBR & Psychrophilic sequence batch reactor \\
\hline SBR & Sequence batch reactor \\
\hline SMY & Specific methane yields \\
\hline STP & Standard temperature and pressure $(273 \mathrm{~K} ; 1 \mathrm{~atm})$ \\
\hline TCL & Treatment cycle length \\
\hline TCOD & Total chemical oxygen demand \\
\hline TS & Total solids \\
\hline VFAs & Volatile fatty acids \\
\hline VS & Volatile solids \\
\hline WAD & Wet anaerobic digestion \\
\hline
\end{tabular}

suitable for on-farm conditions, but there is need to invent and introduce ideal technologies in terms of substrate handling, loading and unloading of bioreactors. However, some technical advancement has been achieved since then. Currently, DAD is relatively a new biotechnology for agricultural wastes and livestock manure (15-20 \% TS). Recently, several studies investigated DAD of undiluted cow manure without bedding in mesophilic and thermophilic batch reactor (Ahn et al. 2010; Böske et al. 2014, 2015; Di Maria et al. 2012; Kusch et al. 2008; Li et al. 2014). Moreover, a novel process for psychrophilic $\left(20^{\circ} \mathrm{C}\right) \mathrm{DAD}$ of undiluted cow manure without bedding (TS $=12-16 \%$ ) in a sequence batch reactor has been reported recently (Massé and Saady 2015b) and for cow feces with bedding (wheat straw; TS $=27 \%$; Massé and Saady 2015c). These researchers reported a SMY of $182.9 \pm 16.9{ }_{\mathrm{N}} \mathrm{CH}_{4} \mathrm{~kg}^{-1}$
VS fed at organic loading rate (OLR) of $3.0 \mathrm{~g}$ TCOD kg ${ }^{-1}$ inoculum day ${ }^{-1}$ in sequence batch reactor (SBR). Investors prefer increasing the OLR to decrease the bioreactor size and lower the capital and operation costs. The effect of OLR on the performance of cow manure DAD has not been studied sufficiently. Hence, feasibility of high-rate PDAD of cow feces with bedding (TS $=27 \%$ ) is still unanswered question. The $27 \%$ TS in feed was targeted because cattle in sheds with straw bed produce manure of around $27 \%$ TS (Demirer and Chen 2008). This study aims to:

1. Increase the OLR by 12.5 and $25 \%$ (to 9.0 and $10.0 \mathrm{~g} \mathrm{TCOD} \mathrm{kg}^{-1}$ inoculum day ${ }^{-1}$ ) in comparison with previously published data $(8.0 \mathrm{~g}$ TCOD $\mathrm{kg}^{-1}$ inoculum day ${ }^{-1}$ ).

2. Demonstrate the feasibility of PDAD of CFWS (TS $=27 \%)$ at the above-stated conditions.

3. Evaluate effect of increasing substrate OLR and decreasing the inoculum-to-substrate ratio (ISR) on the long-term performance.

\section{Materials and methods}

\section{Experimental setup}

The experiments were designed to assess the influence of the OLR (9.0 and $10.0 \mathrm{~g}$ TCOD kg$^{-1}$ inoculum day ${ }^{-1}$ ) on $\mathrm{CH}_{4}$ production and process stability of PDAD. The feed was CFWS at feed total solids of $27 \%$ over three successive cycles (63 days) at each OLR. The reactors operated at both OLRs were operated in parallel to exclude the variation in feed and other experimental conditions.

\section{Bioreactor}

The experimental work utilized cylindrical plastic drums (volume $=40 \mathrm{~L}$ ) as bioreactors. The bioreactors were operated as psychrophilic sequential batch reactors (PSBR) at 21 days treatment cycle length (TCL). The cycle is composed of the following steps: day 1: inoculating the reactor with mixed anaerobic culture obtained from the previous cycle, feeding the substrate, and mixing the inoculum and substrate (all were in aerobic condition); days 1-21: anaerobic reaction; and day 21: emptying the digestate (in aerobic condition) and starting the next cycle as in step 1. The bioreactors were kept in a temperaturecontrolled room $\left(20^{\circ} \mathrm{C}\right)$. Two gas lines were connected to the reactor's cover (Fig. 1). The first gas line was used for flushing nitrogen $\left(\mathrm{N}_{2}\right)$ gas immediately after feeding phase to create the anaerobic atmosphere inside the bioreactor. The second gas line was used as gas outlet connected to a 
Table 2 Physicochemical characteristics of the cow feces fed in each treatment cycle

\begin{tabular}{lccc}
\hline Parameter & Cow feces & & Wheat straw \\
\cline { 2 - 3 } & Cycle 1 & Cycles 2-3 & Cycles 1-3 \\
\hline $\mathrm{pH}$ & 6.74 & 7.02 & $\mathrm{NA}$ \\
Total chemical oxygen demand (TCOD; $\mathrm{g} \mathrm{kg}^{-1}$ ) & 169.0 & 180.0 & 1097 \\
Total solids (TS; \%) & 12.6 & 12.8 & 89.0 \\
Volatile solids (VS; $\%)$ & 11.5 & 11.8 & 84.9 \\
Volatile fatty acids $\left(\mathrm{g} \mathrm{kg}^{-1}\right)$ & & & \\
Acetate & 4.01 & 2.93 & $\mathrm{NA}$ \\
Propionate & 1.41 & 0.86 & $\mathrm{NA}$ \\
Butyrate & 2.35 & 0.55 & $\mathrm{NA}$ \\
Fiber components (\% of dry matter) & & & \\
Cellulose (\% of dry matter) & 26.33 & 24.69 & 38.61 \\
Hemi-cellulose (\% of dry matter) & 16.35 & 26.06 & 25.14 \\
Lignin (\% of dry matter) & 10.67 & 10.77 & 7.3 \\
\hline
\end{tabular}

Values given are averages of duplicate samples

NA not applicable

\begin{tabular}{|c|c|c|c|c|c|c|}
\hline Parameters & Cycle 1 & Cycle 2 & Cycle 3 & Cycle 1 & Cycle 2 & Cycle 3 \\
\hline OLR $\left(\mathrm{g}^{\mathrm{TCOD} \mathrm{kg}}{ }^{-1}\right.$ inoculum day $\left.{ }^{-1}\right)$ & 9.0 & 9.0 & 9.0 & 10.0 & 10.0 & 10.0 \\
\hline OLR ( $\mathrm{g} \mathrm{VS} \mathrm{fed} \mathrm{kg}^{-1}$ inoculum day ${ }^{-1}$ ) & 6.6 & 6.5 & 6.5 & 7.4 & 7.2 & 7.2 \\
\hline Cow feces $(\mathrm{kg})$ & 2.721 & 2.685 & 2.685 & 3.024 & 2.983 & 2.983 \\
\hline Wheat straw $(\mathrm{kg})$ & 0.614 & 0.593 & 0.593 & 0.683 & 0.659 & 0.659 \\
\hline ISR (VS-based) & 1.28 & 1.26 & 1.48 & 1.25 & 1.20 & 1.37 \\
\hline Feed TCOD/VS ratio & 1.36 & 1.38 & 1.38 & 1.36 & 1.38 & 1.38 \\
\hline TCOD fed $(\mathrm{g})$ & 1134 & 1134 & 1134 & 1260 & 1260 & 1260 \\
\hline VS fed $(g)$ & 835 & 821 & 821 & 928 & 912 & 912 \\
\hline
\end{tabular}

In all cycles the reactors have been inoculated with $6 \mathrm{~kg}$ of inoculum (culture) which has been transferred from the previous cycle. The feed TS has been kept at $27 \%$ in all cycles

$O L R$ organic loading rate, TCOD total chemical oxygen demand, VS volatile solids, ISR inoculum-tosubstrate ratio

wet tip tank meter which measures the volume of the biogas generated. Details of the wet tip tank have been given elsewhere (Saady and Massé 2015).

\section{Inoculum and substrate}

The initial inoculum (used in the first cycle) was mixed anaerobic culture (TS $=27 \%$ ) obtained from a laboratory scale PDAD-SBR digesting dairy cow feces with bedding (wheat straw; $27 \%$ TS; Massé and Saady 2015c). Dairy cow feces was obtained from the dairy farm of the Dairy and Swine Research and Development Centre (DSRDC), Sherbrooke, Quebec. Feces were collected into plastic drums and measures were taken to avoid contamination of the collected feces with urine and bedding. The feces drums were stored at $4{ }^{\circ} \mathrm{C}$ until the feces has been fed to the reactors. Table 2 gives the physicochemical characteristics of the cow feces fed in the successive treatment cycles.
Wheat straw has been chopped to $3 \mathrm{~mm}$ particles using a laboratory mill (Thomas Wiley Laboratory Mill Model 4, Arthur H. Thomas Company, Philadelphia, PA, USA). Chopped wheat straw and cow feces were mixed and homogenized using manual scoop to achieve a substrate TS content $(27 \%)$ and OLRs of 9.0 and $10.0 \mathrm{~g}_{\text {TCOD kg }}^{-1}$ inoculum day ${ }^{-1} \quad(6.53 \pm 0.06$ and $7.27 \pm 0.12 \mathrm{~g} \mathrm{VS}$ $\mathrm{kg}^{-1}$ inoculum day ${ }^{-1}$ ).

\section{Organic loading rate}

Table 3 gives the mass of inoculum, feces, and/or straw fed to each bioreactor at the beginning of the successive cycles. The OLR has been calculated using the masses of VS and TCOD of the CFWS fed (Tables 2, 3). Table 4 gives the physicochemical characteristics of the inoculum and inoculum-substrate mixture (ISM) prior to being fed to the bioreactors. The inoculum-to-substrate ratio (ISR) was expressed in $\mathrm{kg}$ VS of inoculum per $\mathrm{kg}$ of total VS fed and OLR was expressed in $\mathrm{g}$ of 
Table 4 Physico-chemical characteristics of the inoculum and inoculum-substrate mixture (ISM) at the beginning of each digestion cycle

\begin{tabular}{lcc}
\hline Parameters & Cycles 1, 2,3 & Cycles $1,2,3$ \\
\hline OLR (g TCOD kg ${ }^{-1}$ inoculum day ${ }^{-1}$ ) & 9.0 & 10.0 \\
Alkalinity ISM & 9.25 & 9.8 \\
pH Inoculum & 8.16 & 8.05 \\
pH ISM & 7.75 & 7.76 \\
TS Inoculum (\%) & 19.67 & 20.5 \\
TS ISM (\%) & 22.6 & 21.9 \\
VS Inoculum (\%) & 18.3 & 18.6 \\
VS ISM (\%) & 20.8 & 19.9 \\
Acetate Inoculum $\left(\mathrm{g} \mathrm{kg}^{-1}\right)$ & 0.27 & 0.30 \\
Acetate ISM (g kg $\left.{ }^{-1}\right)$ & 1.07 & 1.28 \\
Propionate Inoculum $\left(\mathrm{g} \mathrm{kg}^{-1}\right)$ & 0.06 & 0.15 \\
Propionate ISM $\left(\mathrm{g} \mathrm{kg}^{-1}\right)$ & 0.32 & 0.33 \\
Butyrate inoculum $\left(\mathrm{g} \mathrm{kg}^{-1}\right)$ & 0.03 & 0.67 \\
Butyrate inoculum $\left(\mathrm{g} \mathrm{kg}^{-1}\right)$ & 0.18 & 0.15 \\
\hline
\end{tabular}

Values given are averages of six samples

$O L R$ organic loading rate, ISM inoculum-substrate mixture, TS total solids, VS volatile solids

TCOD fed per kg of inoculum, and in $\mathrm{g}$ of total VS fed per $\mathrm{kg}$ of inoculum per day. The average of ISR was $1.34 \pm 0.12$ at OLR of $9.0 \mathrm{~g}$ TCOD kg$^{-1}$ inoculum day ${ }^{-1}$ and $1.27 \pm 0.09$ at OLR of $10.0 \mathrm{~g} \mathrm{TCOD} \mathrm{kg}^{-1}$ inoculum day ${ }^{-1}$.

\section{Sampling}

Samples of the inoculum and substrate mixture (ISM) were taken on day (0) immediately after feeding and on day (21) at the end of the treatment cycle. It was also sampled on day (7) by opening the reactor, mixing and homogenizing its content manually for $5 \mathrm{~min}$ to obtain a representative sample. The sample obtained on day (21) represented the digestate (effluent) of which $6 \mathrm{~kg}$ were used as inoculum in the next cycle. Anaerobic condition was established on day (0) immediately after feeding by flushing the reactor with nitrogen. The biogas was sampled by $10 \mathrm{~mL}$ plastic syringe through septa-sealed gas sampling port installed on the second gas line.

\section{Biogas measurement}

Daily measurements were taken for the volume of the biogas produced using wet tip gas meters. The components of biogas $\left(\mathrm{CH}_{4}, \mathrm{H}_{2} \mathrm{~S}, \mathrm{CO}_{2}\right)$ were determined weekly on a MicroGC 490 gas chromatograph (GC) (Agilent Technologies, China).

Specific $\mathrm{CH}_{4}$ yield (SMY) in each cycle was determined by dividing the cumulative $\mathrm{CH}_{4}$ volume produced (within 21 days) by the mass of volatile solids (VS) fed to the bioreactor at the start of the cycle. Methane $\left(\mathrm{CH}_{4}\right)$ production is given in normalized litres ${ }_{\mathrm{N}} \mathrm{L} \mathrm{CH}_{4}$ by correcting its volume to standard temperature and pressure (STP; $\left.273^{\circ} \mathrm{K} ; 1 \mathrm{~atm}\right)$.

\section{Analytical methods}

Total solids (TS), volatile solids (VS), and $\mathrm{pH}$ were determined weekly while total chemical oxygen demand (TCOD) and alkalinity were measured at the beginning and end of the treatment cycle according to Standard Methods (APHA 1992).

The levels of volatile fatty acids (VFAs) from acetic to isovaleric acids were measured weekly on Perkin Elmer GC model 8310 (Perkin Elmer, Waltham, MA, USA) equipped with an autosampler to facilitate the analysis. The column, GC setup and analytical protocol have been reported elsewhere (Massé et al. 2003).

\section{Fiber analysis}

The cellulose, hemicellulose, and lignin components of the fiber have been determined through fiber analysis performed on duplicate samples of the raw cow feces and wheat straw separately for each batch of these substrates. Hemicellulose has been determined by subtracting the quantity of acid detergent fiber (ADF) from the quantity of neutral detergent fiber (NDF). Cellulose was determined by subtracting the quantity of acid detergent lignin (ADL) from the quantity of acid detergent fiber (ADF) (Bauer et al. 2009).

\section{Statistical methods}

Data presented in tables and shown in figures are the means and standard deviations of duplicate measurements. Statistical analysis was carried out using Minitab v. 14 
statistical software (Minitab Inc., PA, USA). Data were analyzed by one-way ANOVA, followed by post hoc multiple comparisons (Tukey's test) with a confidence level of $95 \%$ (i.e., $p<0.05$ ).

\section{Results and discussion}

\section{Methane production}

The long-term performance of PDAD-SBR was assessed in three cycles at each OLR (9.0 and $10.0 \mathrm{~g}^{\mathrm{TCOD} \mathrm{kg}}^{-1}$ inoculum day ${ }^{-1}$ ). Figure 2 shows the cumulative specific methane yield (SMY) obtained in each treatment cycle while Table 5 gives the maximum SMYs calculated during each treatment cycle.

The overall average SMY at OLR of 9.0 and $10.0 \mathrm{~g} \mathrm{TCOD} \mathrm{kg}^{-1}$ inoculum day ${ }^{-1}$ is $134.0 \pm 7.7$, $136.4 \pm 4.9{ }_{\mathrm{N}} \mathrm{L} \mathrm{CH}_{4} \mathrm{~kg}^{-1} \mathrm{VS}$ fed $(97.6 \pm 6.3$ and

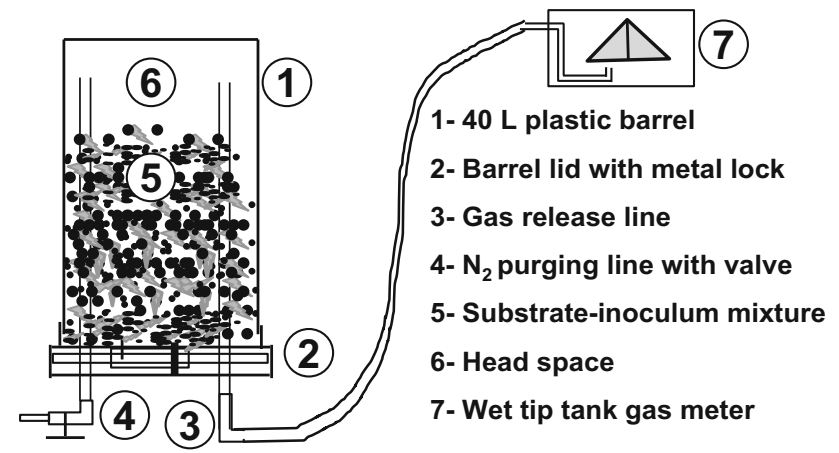

Fig. 1 Schematic diagram of the dry anaerobic digester (Massé and Saady 2015c)

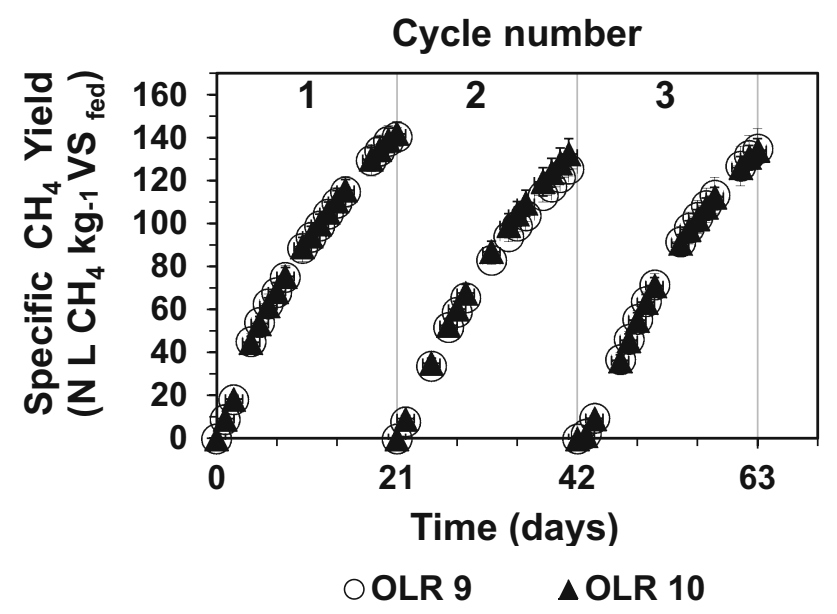

Fig. 2 Specific methane yield for the psychrophilic dry anaerobic digestion of cow feces and wheat straw (27\% TS) at OLR $=9$ (open circle) and OLR $=10$ (filled triangle)
$99.3 \pm 4.5{ }_{N} \mathrm{~L} \mathrm{CH}_{4} \mathrm{~kg}^{-1}$ TCOD fed), respectively. The coefficient of variation of the SMY between the duplicate reactors fed at OLR $9.0 \mathrm{~g} \mathrm{TCOD} \mathrm{kg}^{-1}$ inoculum day ${ }^{-1}$ was $5.76 \pm 2.80 \%$ while for the reactors fed at OLR $10.0 \mathrm{~g} \mathrm{TCOD} \mathrm{kg}^{-1}$ inoculum day ${ }^{-1}$ it was $3.58 \pm 0.92 \%$ without a significant statistical difference according to Tukey's multiple comparison test at $95 \%$ confidence interval. This indicates that the performance of the PDAD-SBRs was not influenced by the $11.1 \%$ increase in OLR. It seems that the quality of cow feces fed affected the performance of psychrophilic anaerobic sequence batch reactor digesting $27 \%$ total solids more than the increase in organic loading rate. The cow feces which has been fed during cycle 1 had lower TCOD and VS values $\left(\approx 169.0 \mathrm{~g}\right.$ TCOD kg$^{-1}$ feces, $11.1 \%$ VS, respectively) in comparison with the feces fed in cycles 2-3 (180.0 $\mathrm{g}_{\text {TCOD kg}}{ }^{-1}$ feces, $11.2 \%$ VS, respectively). However, the SMYs $\left(140.4 \pm 4.5\right.$ and $141.8 \pm 5.4{ }_{\mathrm{N}} \mathrm{L} \mathrm{CH}_{4} \mathrm{~kg}^{-1} \mathrm{VS}$ fed at OLR 9.0 and $10.0 \mathrm{~g} \mathrm{TCOD} \mathrm{kg}^{-1}$ inoculum day ${ }^{-1}$, respectively) obtained during cycle 1 were greater than that obtained during cycle $2-3 \quad(125.4 \pm 3.3$ and $132.4 \pm 7.8 \mathrm{~N} \mathrm{CH}_{4} \mathrm{~kg}^{-1} \mathrm{VS}$ fed at OLR 9.0 and $10.0 \mathrm{~g} \mathrm{TCOD} \mathrm{kg}^{-1}$ inoculum day ${ }^{-1}$ during cycle 2, respectively). This could be partially explained by the higher concentrations of VFAs in the feces used during cycle 1 compared to that fed in cycle $2-3$. Cow feces fed in cycle 1 contained 37, 64.0, and $327 \%$ more acetic, propionic, and butyric acids compared to the cow feces used in cycle 2-3.

Methane formed between $53.0 \pm 0.6$ and $57.6 \pm 0.0 \%$ of the biogas produced by volume. The overall average of methane percentage in biogas was $55.8 \pm 1.4$ and $55.6 \pm 1.1$ at OLR of 9.0 and $10.0 \mathrm{~g} \mathrm{TCOD} \mathrm{kg}^{-1}$ inoculum day ${ }^{-1}$, respectively (Fig. 3) and they were statistically the same. Somayaji and Khanna (1994) reported that $\mathrm{CH}_{4}$ percentage in biogas was around 58-59\% for wet anaerobic digestion of $10 \%$ TS feed (cow manure and wheat straw mixture) at hydraulic retention time (HRT) of 40 days. They observed that changing the percentage of wheat straw total solids in feed from 20 to 40, 60, and $80 \%$ did not affect the percentage of methane in biogas though it affected the SMY. On the contrary, Hashimoto (1983) reported $31 \%$ $\mathrm{CH}_{4}$ in biogas when $7.8 \%$ TS feed of 50:50 (mass ratio) of cow manure and wheat straw was anaerobically digested at HRT of 15 days. Increasing the mass ratio of wheat straw in feed to 75 and $90 \%$ decreased $\mathrm{CH}_{4}$ proportion in biogas to $16 \%$.

Wheat straw contributed on average between $67.4 \pm 0.4 \%$ of the feed total fibers; $58.1 \pm 1.1 \%$ of the feed TCOD; $61.8 \pm 0.6 \%$ of the feed VS and $18.2 \pm 0.2$ of feed mass at the examined OLRs (Table S1). Notice that 
Table 5 Specific methane yields and rates of methane production for the psychrophilic dry anaerobic digestion of cow feces and wheat straw $(27 \% \mathrm{TS})$

\begin{tabular}{|c|c|c|c|c|c|c|}
\hline Parameters & Cycle 1 & Cycle 2 & Cycle 3 & Cycle 1 & Cycle 2 & Cycle 3 \\
\hline \multicolumn{7}{|l|}{ Organic loading rate (OLR) } \\
\hline 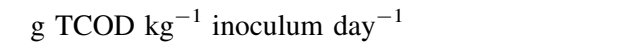 & 9.0 & 9.0 & 9.0 & 10.0 & 10.0 & 10.0 \\
\hline $\mathrm{g} \mathrm{VS} \mathrm{fed} \mathrm{kg}^{-1}$ inoculum day ${ }^{-1}$ & 6.6 & 6.5 & 6.5 & 7.4 & 7.2 & 7.2 \\
\hline Cow feces TCOD $\left(\mathrm{g} \mathrm{kg}^{-1}\right)$ & 169.0 & 180.0 & 180.0 & 169.0 & 180.0 & 180.0 \\
\hline \multicolumn{7}{|l|}{ Specific methane yield (SMY) } \\
\hline${ }_{\mathrm{N}} \mathrm{L} \mathrm{CH}_{4} \mathrm{~kg}^{-1} \mathrm{VS}$ & $140.4 \pm 4.5$ & $125.4 \pm 3.3$ & $136.2 \pm 10.5$ & $141.8 \pm 5.4$ & $132.4 \pm 7.2$ & $134.9 \pm 5.1$ \\
\hline${ }_{N} \mathrm{~L} \mathrm{CH}_{4} \mathrm{~kg}^{-1} \mathrm{TCOD}$ & $103.4 \pm 3.3$ & $90.8 \pm 2.4$ & $98.6 \pm 7.6$ & $104.4 \pm 4.0$ & $95.8 \pm 5.2$ & $97.7 \pm 3.7$ \\
\hline Rate of $\mathrm{CH}_{4}$ production $\left({ }_{\mathrm{N}} \mathrm{L} \mathrm{CH}_{4} \mathrm{~kg}^{-1} \mathrm{VS}\right.$ day $\left.{ }^{-1}\right)$ & $6.7 \pm 0.2$ & $6.0 \pm 0.2$ & $6.5 \pm 0.5$ & $6.8 \pm 0.3$ & $6.3 \pm 0.4$ & $6.4 \pm 0.3$ \\
\hline
\end{tabular}

The numbers given are averages and standard deviations of duplicate bioreactors

The treatment cycle length (TCL) in each cycle was 21 days

Values given are averages of duplicate samples

TCOD total chemical oxygen demand, $\mathrm{VS}$ volatile solids, $\mathrm{CH}_{4}$ methane

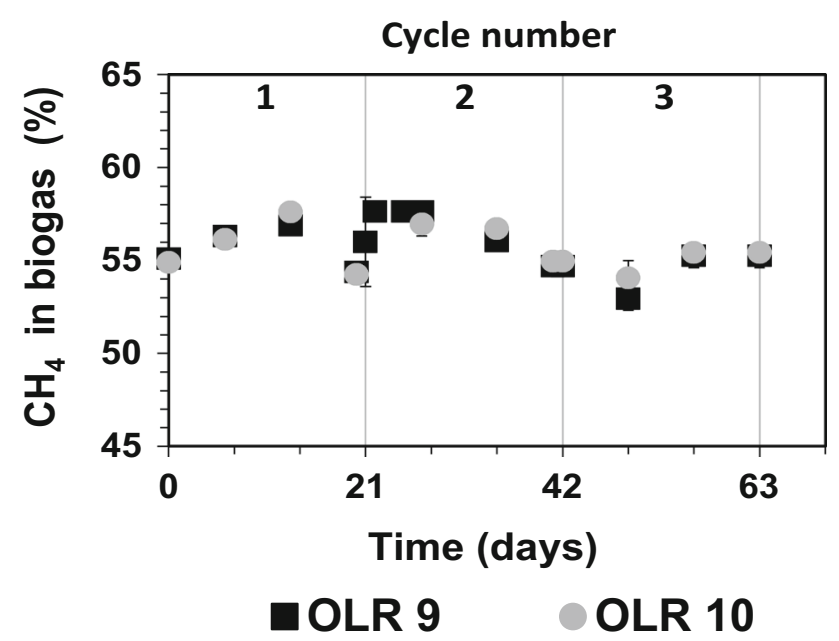

Fig. 3 Percentage of methane in biogas for the psychrophilic dry anaerobic digestion of cow feces and wheat straw (27\% TS)

SMY calculated at OLR $9.0 \mathrm{~g}^{\mathrm{TCOD} \mathrm{kg}}{ }^{-1}$ inoculum day $^{-1}$ during cycle 1 was greater than that obtained in cycle 2 and 3 by 10.7 and $3.0 \%$, respectively. Similarly, SMY obtained at OLR $10.0 \mathrm{~g}^{\mathrm{T} C O D ~ ~^{-1}}$ inoculum day $^{-1}$ during cycle 1 was greater than that obtained in cycle 2 and 3 by 6.6 and $4.9 \%$, respectively. The lower SMY obtained during cycles 2-3 compared to that obtained in cycle 1 (at both OLRs examined) could be partially due to the less wheat straw fiber fed. Notice that the mass of wheat straw fiber in the feed for cycle 2 and 3 were 13 and $15 \mathrm{~g}$ less than that fed in cycle 1, respectively; Table S1. Lignocellulose fiber such as cellulose biodegrades slowly during anaerobic digestion thus stipulates long retention time. Hydrolysis reactions of lignocellulose fiber are rate limiting because of physicochemical and compositional factors in the structure of fiber (Kumar et al. 2009; Noike et al. 1985). This phenomenon is especially important when the substrate is in solid or particulate form similar to cow manures (Myint and Nirmalakhandan 2006).

Somayaji and Khanna (1994) reported that changing the proportion of wheat straw in the feed mixture affected the SMY but not $\mathrm{CH}_{4}$ percentage in biogas while Hashimoto (1983) reported that it affected both of them.

Overall average specific $\mathrm{CH}_{4}$ production rate ${ }_{\mathrm{N}} \mathrm{L} \mathrm{CH}_{4}$ $\mathrm{kg}^{-1} \mathrm{VS} \mathrm{day}^{-1}$ ) obtained at OLR of 9.0 and $10.0 \mathrm{~g} \mathrm{TCOD} \mathrm{kg}^{-1}$ inoculum day ${ }^{-1}$ is $6.4 \pm 0.4$ and $6.5 \pm 0.2{ }_{\mathrm{N}} \mathrm{CH}_{4} \mathrm{~kg}^{-1} \mathrm{VS}$ fed, respectively. These values are statistically the same which implies that there is no difference in terms of biogas production rate between the operation at OLR of 9.0 or $10.0 \mathrm{~g}^{\text {TCOD kg}}{ }^{-1}$ inoculum day ${ }^{-1}$.

Except the recently published studies (Massé and Saady 2015a, c; Saady and Massé 2015), no information has been published on the psychrophilic anaerobic digestion of CFWS at high total solids $(>20 \%)$ and high OLR

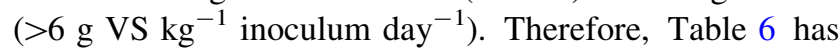
been compiled by comparing the results with the recent data published by the authors of this study. Moreover, the results were compared with the data from mesophilic and thermophilic DAD of relevant substrates. Generally, the SMY ( ${ }_{\mathrm{N}} \mathrm{CH}_{4} \mathrm{~kg}^{-1} \mathrm{VS}$ fed) obtained from digesting CFWS mixture (27\% TS) at $20{ }^{\circ} \mathrm{C}$ during 21 days decreased from $182.9 \pm 16.9$ to $136.4 \pm 4.9$ as the OLR increased from 3.0 to $10.0 \mathrm{~g} \mathrm{TCOD} \mathrm{kg}^{-1}$ inoculum day ${ }^{-1} \quad(2.2 \pm 0.2$ to $7.3 \pm 0.1 \mathrm{~g} \mathrm{VS} \mathrm{kg}^{-1}$ inoculum day ${ }^{-1}$ ). The overall average SMYs of the 3 cycles fed at OLR of 9.0 and $10.0 \mathrm{~g} \mathrm{TCOD} \mathrm{kg}^{-1}$ inoculum day ${ }^{-1}(6.53 \pm 0.06$ and $7.27 \pm 0.12 \mathrm{~g} \mathrm{VS}$ fed $\mathrm{kg}^{-1}$ inoculum day ${ }^{-1}$ ) obtained in this study after 21 days of psychrophilic $\left(20^{\circ} \mathrm{C}\right)$ incubation were $134.0 \pm 7.7$ and $136.4 \pm 4.9{ }_{\mathrm{N}} \mathrm{L} \mathrm{CH}_{4} \mathrm{~kg}^{-1} \mathrm{VS}$ fed, respectively. These SMYs are lower than the $160 \mathrm{~N}$ $\mathrm{L} \mathrm{CH}_{4} \mathrm{~kg}^{-1}$ VS of dairy manure, straw, and oat husk (fed at 
Table 6 Comparative performance of dry anaerobic digestion of cow manure and wheat straw

\begin{tabular}{|c|c|c|c|c|c|c|c|}
\hline Substrate & $\begin{array}{l}\mathrm{TS} \\
(\%)\end{array}$ & ISR & $\begin{array}{l}\text { OLR } \\
\left(\mathrm{g} \mathrm{VS} \mathrm{kg}^{-1}\right. \\
\left.\text { inoculum day }^{-1}\right)\end{array}$ & $\begin{array}{l}\text { Temp. } \\
\left({ }^{\circ} \mathrm{C}\right)\end{array}$ & $\begin{array}{l}\text { TCL } \\
\text { (days) }\end{array}$ & $\begin{array}{l}\text { SMY } \\
\left(\mathrm{L} \mathrm{kg}^{-1} \mathrm{VS}\right)\end{array}$ & References \\
\hline \multirow{8}{*}{$\begin{array}{l}\text { Dairy manure } \\
\text { and wheat straw }\end{array}$} & 27 & $1.45 \pm 0.02$ & $7.3 \pm 0.1$ & 20 & 21 & $136.4 \pm 4.9$ & This study \\
\hline & 27 & $1.64 \pm 0.03$ & $6.3 \pm 0.1$ & 20 & 21 & $134.0 \pm 7.7$ & This study \\
\hline & 27 & $1.66 \pm 0.01$ & $5.2 \pm 0.1$ & 20 & 21 & $143.2 \pm 11.7$ & Massé and Saady (2015a) \\
\hline & 27 & $1.45 \pm 0.02$ & $5.8 \pm 0.0$ & 20 & 21 & $147.1 \pm 17.2$ & Massé and Saady (2015a) \\
\hline & 27 & $1.4 \pm 0.05$ & $4.4 \pm 0.1$ & 20 & 21 & $175.4 \pm 11.9$ & Saady and Massé (2015) \\
\hline & 27 & $1.7 \pm 0.05$ & $3.7 \pm 0.1$ & 20 & 21 & $193.8 \pm 11.8$ & Saady and Massé (2015) \\
\hline & 27 & $2.9 \pm 0.1$ & $2.9 \pm 0.1$ & 20 & 21 & $179.8 \pm 20.4$ & Saady and Massé (2015) \\
\hline & 27 & $5.56 \pm 0.01$ & $2.2 \pm 0.2$ & 20 & 21 & $182.9 \pm 16.9$ & Massé and Saady (2015b) \\
\hline Cattle manure & 12 & $0.014-0.057$ & & 35 & 80 & $112-191$ & Sunarso et al. (2012) \\
\hline $\begin{array}{l}\text { Sheep manure } \\
\text { (dry anaerobic digestion) }\end{array}$ & & $\begin{array}{l}1.36 \\
\text { (mass based) }\end{array}$ & 0.81 & 35 & 94 & $184^{\mathrm{c}}$ & Blanco et al. (2010) \\
\hline Animal manure & & $\begin{array}{l}1.0 \\
\text { (VS-based) }\end{array}$ & 2.4 & 35 & 47 & $216 \pm 40$ & Frigon et al. (2012) \\
\hline \multirow[t]{3}{*}{ Cow manure and crop silage } & & NR & 4.45 & & & 237.6 & Comino et al. (2010) \\
\hline & & & 5.15 & & & 249 (stable) & \\
\hline & & & 7.78 & & & 61.6 (failure) & \\
\hline \multirow[t]{2}{*}{ Cattle slurry } & & NR & 2.44 & 35 & NR & 400 & Mahnert and linke (2009) \\
\hline & & & 3.25 & & & 370 & \\
\hline Cow manure and crop silage & & NR & 4.25 & 39 & 75 & $360^{\mathrm{c}}$ & Lindorfer et al. (2008) \\
\hline Beef manure plus straw & 18 & NR & 3.2 & 32 & 28 & 181 & Schäfer et al. (2006) \\
\hline \multirow[t]{2}{*}{ Dairy manure, straw, and oat husk } & 17 & NR & 3.4 & 38 & 22 & 160 & Schäfer et al. (2006) \\
\hline & & & 4.1 & 38 & 22 & 84 & \\
\hline \multirow{3}{*}{$\begin{array}{l}\text { Rice straw and corn stover } \\
\text { inoculated with }(1: 1) \text { sewage } \\
\text { sludge, pig manure }\end{array}$} & 25 & 0.2 & NR & $26-28$ & 198 & 382 & Sun et al. (1987) \\
\hline & 30 & & & & 198 & 423 & \\
\hline & 35 & & & & & 34 & \\
\hline \multirow[t]{3}{*}{ Fresh horse manure and straw } & 20 & 0.2 & NR & 37 & 28 & 146 & Kusch et al. (2008) \\
\hline & & & & & 42 & 175 & \\
\hline & & & & & 72 & 208 & \\
\hline \multirow{3}{*}{$\begin{array}{l}\text { Cow manure and wastewater sludge } \\
(2: 3 \text { mass ratio })\end{array}$} & 16 & 0.2 & $0.35^{\mathrm{a}}$ & 35 & 63 & 328 & Li et al. (2011) \\
\hline & & & & & & 251 & \\
\hline & & & & & & 319 & \\
\hline $\begin{array}{l}\text { Beef manure and grass silage } \\
(85 \%: 15 \%)\end{array}$ & 28 & NR & $0.9^{\mathrm{b}}$ & 35 & 100 & 227 & Schäfer et al. (2006) \\
\hline
\end{tabular}

$T C L$ treatment cycle length, $V S$ volatile solids, $N R$ not reported

${ }^{a}$ Organic loading rate (OLR) units are $\mathrm{kg}^{\mathrm{T}} \mathrm{TCOD} \mathrm{\textrm {kg } ^ { - 1 }} \mathrm{VS}$

b OLR units are $\mathrm{kg}$ TCOD kg ${ }^{-1} \mathrm{VS}_{\text {day }}{ }^{-1}$

c Specific methane yield (SMY) units are ${ }_{\mathrm{N}} \mathrm{L} \mathrm{CH}_{4} \mathrm{~kg}^{-1}$ VS

TS $17 \%$ and OLR of $3.4 \mathrm{~g} \mathrm{VS} \mathrm{kg}^{-1}$ inoculum day ${ }^{-1}$ ) and digested at $38{ }^{\circ} \mathrm{C}$ during 22 days in Järna biogas plant in Sweden (Schäfer et al. 2006).

Compared to the data reported by Schäfer et al. (2006) for the Järna biogas plant, this study increased the OLR from 3.4 to $7.27 \pm 0.12 \mathrm{~g} \mathrm{VS}$ fed $\mathrm{kg}^{-1}$ inoculum day ${ }^{-1}$, increased the substrate TS from 17 to $27 \%$, and decreased the operation temperature from 38 to $20{ }^{\circ} \mathrm{C}$ without losing more than $15.6 \%$ of the SMY. Obviously, the increase in OLR, TS, and the decrease in operation temperature means reduction in capital and operational costs and increase in the net energy yield and in the return-on-investment.

The average SMYs $(134.0 \pm 7.7$ and $136.4 \pm 4.9 \mathrm{~N}-$ $\mathrm{L} \mathrm{CH}_{4} \mathrm{~kg}^{-1}$ VS fed) obtained in this study at OLR of $6.5 \pm 0.1$ and $7.3 \pm 0.1 \mathrm{~g} \mathrm{VS} \mathrm{kg}^{-1}$ inoculum day ${ }^{-1}$ constitute $75 \%$ of the SMY (181 L CH $\left.\mathrm{Lg}^{-1} \mathrm{VS}\right)$ obtained from digesting beef manure and straw mixture (TS $18 \%$ ) at OLR of $3.2 \mathrm{~g} \mathrm{VS} \mathrm{kg}^{-1}$ inoculum day ${ }^{-1}$ in mesophilic condition $\left(32{ }^{\circ} \mathrm{C}\right)$ during 28 days (Schäfer et al. 2006; Table 6). In comparison with Schäfer's et al. (2006) result, 
this study increased the feed TS by $30 \%$, increased the OLR by $103-128 \%$, and shortened TCL by $25 \%$. Increasing the OLR from 3.2 to $7.3 \mathrm{~g} \mathrm{VS} \mathrm{kg}^{-1}$ inoculum day ${ }^{-1}$ decreased the required bioreactor's size by $55 \%$. It is worthwhile to notice that digesting cow manure and wastewater sludge mixture (61\% TS) anaerobically at very low OLR (0.35 $\mathrm{g} \mathrm{TCOD} \mathrm{kg}^{-1}$ inoculum day $\left.{ }^{-1}\right)$ and in relatively long TCL (63 days) yielded $>250{ }_{N} \mathrm{~L} \mathrm{CH}_{4}$ $\mathrm{kg}^{-1} \mathrm{VS}$ fed (Li et al. 2011). Obviously, the yields of $382{ }_{N} \mathrm{~L} \mathrm{CH}_{4} \mathrm{~kg}^{-1} \mathrm{VS}$ fed obtained by Sun et al. (1987) in Table 6 is not practical because of the excessive TCL (198 days) at mesophilic condition $\left(26-28{ }^{\circ} \mathrm{C}\right)$ and that $50 \%$ of the substrate was an energy crop (corn stover). Demonstrating a stable PDAD of cow manure and wheat straw (TS of $27 \%$ ) at high-rate OLR of 9.0 and $10.0 \mathrm{~g} \mathrm{TCOD} \mathrm{kg}^{-1}$ inoculum day ${ }^{-1} \quad(6.3 \pm 0.1 \quad$ and $7.3 \pm 0.1 \mathrm{~g} \mathrm{VS} \mathrm{kg}^{-1}$ inoculum day ${ }^{-1}$ ) during 63 days comprising three successive cycles is an important and promising development. The feed TS of $27 \%$ is very close to the threshold of $30 \%$ above which methanogens were significantly inhibited at $35^{\circ} \mathrm{C}$ during batch anaerobic digestion of cardboard (Abbassi-Guendouz et al. 2012).

Somayaji and Khanna (1994) reported that for $10 \%$ TS feed of cow manure and wheat straw mixture a maximum SMY of $107 \mathrm{~L} \mathrm{~kg}^{-1}$ VS fed was obtained within 40 days HRT when the wheat straw contributed $40 \%$ of the feed TS. The SMY decreased when wheat straw contribution to the feed TS increased to more than $40 \%$ or decreased below it. A $100 \mathrm{~L} \mathrm{CH}_{4} \mathrm{~kg}^{-1} \mathrm{VS}$ fed has been obtained by Hashimoto (1983) from digesting $7.8 \%$ TS feed (50:50 cow manure and wheat straw) at $35{ }^{\circ} \mathrm{C}$ and 15 days HRT. The SMY decreased to 70 and $30 \mathrm{~L} \mathrm{CH}_{4} \mathrm{~kg}^{-1} \mathrm{VS}$ fed when the wheat straw was increased to 75 and $90 \%$ by mass in the feed.

The SMYs achieved in the present study prove that PDAD of cow manure and straw is possible at TS $27 \%$ and OLRs of 9.0 and $10.0 \mathrm{~g} \mathrm{TCOD} \mathrm{kg}^{-1}$ inoculum day ${ }^{-1}$ and its efficiency is comparable to that of mesophilic DAD in terms of SMY and stability.

\section{Effects of inoculum-to-substrate ratio (ISR)}

The ISR examined in this study was decreased from $1.34 \pm 0.12$ at OLR of $9.0 \mathrm{~g} \mathrm{TCOD} \mathrm{kg}^{-1}$ inoculum day ${ }^{-1}$ to $1.27 \pm 0.09$ at OLR of $10.0 \mathrm{~g} \mathrm{TCOD} \mathrm{kg}^{-1}$ inoculum day ${ }^{-1}$ [corresponding to a percentage of substrate-toinoculum (VS-based) of 74.6 and 78.7, respectively].

Generally, the conclusions reported in literature on the effect of ISR on SMY are variable. For example, decreasing the ISR from 3.33 to 1.67 caused $20 \%$ decrease in the SMY from Okra beans refuse (9.5\% TS) mesophilic batch DAD (19 days incubation time; Zhou et al. 2011). Similarly, a decrease in VS-based ISR from 3.0 to 1.0 caused $16 \%$ reduction in SMY during 20 days of batch mesophilic AD of maize (10\% TS; Raposo et al. 2006). On the contrary, for dry grind corn ethanol plant stillage decreasing the VS-based ISR from 3.67 to $1.83,0.92$ and 0.46 , respectively, increased the SMY by 1.25 , 10 , and $14.2 \%$, respectively (Eskicioglu and Ghorbani 2011). These researchers found that the rates of VS and COD removal were lower between ISR 0.46 and 0.92 compared to those at ISR of 1.83 and 3.67. However, lower ISR led to higher percentages of $\mathrm{CH}_{4}$ in biogas which resulted in larger SMYs. Obtaining $134.0 \pm 7.7$ and $136.4 \pm 4.9 \mathrm{~N}$ $\mathrm{L} \mathrm{CH}_{4} \mathrm{~kg}^{-1} \mathrm{VS}$ fed at ISR of $1.34 \pm 0.12$ and $1.27 \pm 0.09$ and TCL of 21 days at psychrophilic conditions $\left(20^{\circ} \mathrm{C}\right)$ is an important advancement in the development of psychrophilic dry anaerobic digestion compared to the SMY values reported by other studies as given in Table 6.

\section{Volatile fatty acids (VFAs) production}

The levels and variations of the VFAs measured in the replicate bioreactors were similar (data not shown). Table 4 gives the concentrations of major VFAs (acetate, propionate, and butyrate) at the beginning (ISM) and end (inoculum) of the treatment cycles conducted at OLR of 9.0 and $10.0 \mathrm{~g} \mathrm{TCOD} \mathrm{kg}^{-1}$ inoculum day ${ }^{-1}$. Generally, at both OLRs examined and during all treatment cycles, acetic acid levels rised upon feeding to around $1500 \pm 710 \mathrm{mg} \mathrm{L}^{-1}$ but were decreased within a week due to the consumption by methanogens. Acetic acid levels were kept around $500 \pm 180 \mathrm{mg} \mathrm{L}^{-1}$ throughout the rest of the cycle revealing that conversion of acetate to methane was not a rate limiting reaction. Similarly, propionic acid levels rised to around $270 \pm 110 \mathrm{mg} \mathrm{L}^{-1}$ upon feedings and were decreased to levels within the instruments' detection limit $\left(30 \pm 10 \mathrm{mg} \mathrm{L}^{-1}\right)$. Profiles of propionic and acetic acids in the replicate bioreactors were similar (data not shown). Except for acetate, generally slight increase in the VFAs concentrations has been observed in samples taken at day 7 which was due to the fast hydrolysis of readily biodegrable part of organics in cow feces.

Butyric acid rised also to concentrations around $170 \pm 40 \mathrm{mg} \mathrm{L}^{-1}$ upon feedings and was decreased to around the instruments' detection limit $\left(25 \pm 10 \mathrm{mg} \mathrm{L}^{-1}\right)$. Isobutyric-, iso-valeric-, and valeric-acids levels were less than $100 \mathrm{mg} \mathrm{L}^{-1}$ after feeding and were kept under $50 \mathrm{mg} \mathrm{L}^{-1}$ during the rest of the TCL. Despite the difference in the OLRs applied the VFAs profiles were similar. Acetogensis reactions from propionate, butyrate and other short-chain fatty acids were not rate limiting as it can be inferred from these acids profiles. 


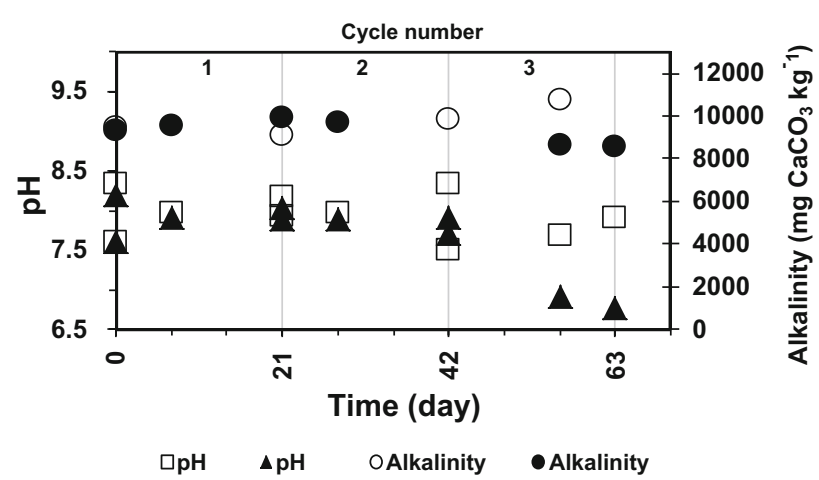

Fig. 4 Alkalinity and pH during psychrophilic dry anaerobic digestion (Open and closed legend are for OLR 9.0 and $10.0 \mathrm{~g}$ TCOD $\mathrm{kg}^{-1}$ inoculum day ${ }^{-1}$, respectively. Two data points are shown at day zero, 21, and 42 for each parameter; one represents the inoculum and the other represents the inoculum-substrate mixture)

The VFAs concentrations and the profiles of $\mathrm{CH}_{4}$ generation during the entire experiment revealed that acetogenesis and methanogenesis progressed sufficiently well. The $\mathrm{pH}$ profiles varied within a narrow range (from $7.76 \pm 0.24$ to $8.18 \pm 0.12$; Fig. 4) likely because of the high alkalinity levels $\left(9270 \pm 250 \mathrm{mg} \mathrm{CaCO}_{3} \mathrm{~kg}^{-1}\right)$ of the digestion matrix.

\section{Solids reduction}

Total solids (TS) and volatile solids (VS) profiles in the duplicate bioreactors operated at each OLR were similar (data not shown). The VS removal averaged around $35.8 \pm 4.3$ and $34.4 \pm 1.2 \%$ at OLR 9.0 and $10.0 \mathrm{~g} \mathrm{TCOD} \mathrm{kg}^{-1}$ inoculum day ${ }^{-1}, \quad$ respectively. Achieved VS removal is comparable to that (32\%) obtained by Somayaji and Khanna (1994) for wet anaerobic digestion of $10 \%$ TS feed [cow manure and wheat straw (40:60 TS-based ratio)] at HRT of 40 days.

\section{Conclusions}

This study reports for the first time successful operation of psychrophilic $\left(20^{\circ} \mathrm{C}\right)$ dry anaerobic digestion (PDAD) of cow feces with wheat straw (CFWS) at $27 \%$ total solids

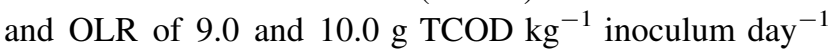
$\left(6.53 \pm 0.06\right.$ and $7.27 \pm 0.12 \mathrm{~g} \mathrm{VS} \mathrm{kg}^{-1}$ inoculum day $^{-1}$, respectively) in relatively short treatment cycle length ( 21 days). The results demonstrated the feasibility of psychrophilic dry anaerobic digestion of cow feces and wheat straw in laboratory scale sequence batch reactor (SBR) with inoculum-to-substrate ratio (VS-based) between $1.34 \pm 0.12$ and $1.27 \pm 0.09$ at the examined OLRs. The average specific methane yields (SMY) were
$134.0 \pm 7.7$ and $136.4 \pm 4.9{ }_{\mathrm{N}} \mathrm{CH}_{4} \mathrm{~kg}^{-1} \mathrm{VS}$ fed at OLR of 9.0 and $10.0 \mathrm{~g} \mathrm{TCOD} \mathrm{kg}^{-1}$ inoculum day ${ }^{-1}$, respectively. Volatile solids removal at ends of the treatment cycles averaged around $35 \%$. Volatile fatty acids concentrations measured during the operation indicated that hydrolysis, but not acetogenesis or methanogenesis, was rate limiting. High-rate PDAD of animal manure and bedding ( $27 \%$ TS) is possible, promising and has a strong potential for application in cold zones.

Open Access This article is distributed under the terms of the Creative Commons Attribution 4.0 International License (http://crea tivecommons.org/licenses/by/4.0/), which permits unrestricted use, distribution, and reproduction in any medium, provided you give appropriate credit to the original author(s) and the source, provide a link to the Creative Commons license, and indicate if changes were made.

\section{References}

Abbassi-Guendouz A, Brockmann D, Trably E, Dumas C, Delgenès J, Steyer J, Escudié R (2012) Total solids content drives high solid anaerobic digestion via mass transfer limitation. Bioresour Technol 111:55-61

Ahn HK, Smith MC, Kondrad SL, White JW (2010) Evaluation of biogas production potential by dry anaerobic digestion of switchgrass-animal manure mixtures. Appl Biochem Biotechnol 160:965-975

APHA (1992) Standard methods for the examination of water and wastewater, 18th edn. American Public Health Association, Washington

Bauer A, Bösch P, Friedl A, Amon T (2009) Analysis of methane potentials of steam-exploded wheat straw and estimation of energy yields of combined ethanol and methane production. J Biotechnol 142:50-55

Blanco D, Lobato A, Fernández C, Escapa A, Gómez X (2010) Batch dry anaerobic codigestion of sheep manure and potato waste. In: Cordovil C, Ferreira L (eds) Proceedings of 14th RAMIRAN International Conference. Lisboa, Portugal

Böske J, Wirth B, Garlipp F, Mumme J, Van den Weghe H (2014) Anaerobic digestion of horse dung mixed with different bedding materials in an upflow solid-state (UASS) reactor at mesophilic conditions. Bioresour Technol 158:111-118

Böske J, Wirth B, Garlipp F, Mumme J, Van den Weghe H (2015) Upflow anaerobic solid-state (UASS) digestion of horse manure: thermophilic vs. mesophilic performance. Bioresour Technol 175:8-16. doi:10.1016/j.biortech.2014.10.041

Brown D, Shi J, Li Y (2012) Comparison of solid-state to liquid anaerobic digestion of lignocellulosic feedstocks for biogas production. Bioresour Technol 124:379-386. doi:10.1016/j. biortech.2012.08.051

Comino E, Rosso M, Riggio V (2010) Investigation of increasing organic loading rate in the co-digestion of energy crops and cow manure mix. Bioresour Technol 101:3013-3019. doi:10.1016/j. biortech.2009.12.025

Demirer GN, Chen S (2008) Anaerobic biogasification of undiluted dairy manure in leaching bed reactors. Waste Manag 28:8. doi:10.1016/j.wasman.2006.11.005

Di Maria F, Gigliotti G, Sordi A, Micale C, Massaccesi L (2012) Start up of a pre-industrial scale solid state anaerobic digestion cell for the co-treatment of animal and agricultural residues. In: ECOS 
2012 - the 25th international conference on efficiency, cost, optimization, simulation and environmental impact of energy systems, Perugia, Italy, June 26-29, 2012

Eskicioglu C, Ghorbani M (2011) Effect of inoculum/substrate ratio on mesophilic anaerobic digestion of bioethanol plant whole stillage in batch mode. Process Biochem 46:1682-1687. doi:10. 1016/j.procbio.2011.04.013

Frigon JC, Roy C, Guiot SR (2012) Anaerobic co-digestion of dairy manure with mulched switchgrass for improvement of the methane yield. Bioprocess Biosyst Eng 35:341-349. doi:10. 1007/s00449-011-0572-5

Hashimoto AG (1983) Conversion of straw-manure mixtures to methane at mesophilic and thermophilic temperatures. Biotechnol Bioeng 25:185-200. doi:10.1002/bit.260250115

Kumar P, Barrett DM, Delwiche MJ, Stroeve P (2009) Methods for pretreatment of lignocellulosic biomass for efficient hydrolysis and biofuel production. Ind Eng Chem Res 48:3713-3729. doi:10.1021/ie801542g

Kusch S, Oechsner H, Jungbluth T (2008) Biogas production with horse dung in solid-phase digestion systems. Bioresour Technol 99:1280-1292

Li J, Jha AK, He J, Ban Q, Chang S, Wang P (2011) Assessment of the effects of dry anaerobic codigestion of cow dung with waste water sludge on biogas yield and biodegradability. Int J Phys Sci 6:3679-3688

Li HL, Guo XL, Cao FF, Wang Y (2014) Process evolution of dry anaerobic co-digestion of cattle manure with kitchen waste. Chem Biochem Eng Q 28:161-166

Lindorfer H, Corcoba A, Vasilieva V, Braun R, Kirchmayr R (2008) Doubling the organic loading rate in the co-digestion of energy crops and manure-A full scale case study. Bioresource Technol 99(5):1148-1156. doi:10.1016/j.biortech.2007.02.033

Mahnert P, Linke B (2009) Kinetic study of biogas production from energy crops and animal waste slurry: effect of organic loading rate and reactor size. Environ Technol 30:93-99. doi:10.1080/ 09593330802246640

Massé DI, Saady NMC (2015a) Dry anaerobic digestion of high solids content dairy manure at high organic loading rates in psychrophilic sequence batch reactor. Appl Microbiol Biotechnol 99:4521-4529. doi:10.1007/s00253-015-6516-2

Massé DI, Saady NMC (2015b) Psychrophilic dry anaerobic digestion of dairy cow feces: long-term operation. Waste Manag 36:86-92. doi:10.1016/j.wasman.2014.10.032
Massé DI, Saady NMC (2015c) Psychrophilic dry anaerobic digestion of high solids content dairy manure: long-term operation. Biol Eng Trans ASABE 7:99-112

Massé DI, Masse L, Croteau F (2003) The effect of temperature fluctuations on psychrophilic anaerobic sequencing batch reactors treating swine manure. Bioresour Technol 89:57-62. doi:10. 1016/S0960-8524(03)00009-9

Myint M, Nirmalakhandan N (2006) Evaluation of first-order, secondorder, and surface-limiting reactions in anaerobic hydrolysis of cattle manure. Environ Eng Sci 23:970-980. doi:10.1089/ees. 2006.23.970

Noike T, Endo G, Juu EC, Yaguchi JI, Matsumoto JI (1985) Characteristics of carbohydrate degradation and the rate-limiting step in anaerobic digestion. Biotechnol Bioeng 27:1482-1489. doi:10.1002/bit.260271013

Raposo F, Banks CJ, Siegert I, Heaven S, Borja R (2006) Influence of inoculum to substrate ratio on the biochemical methane potential of maize in batch tests. Process Biochem 41:1444-1450. doi:10. 1016/j.procbio.2006.01.012

Saady NMC, Massé DI (2015) Impact of organic loading rate on the performance of psychrophilic dry anaerobic digestion of dairy manure and wheat straw: long-term operation. Bioresour Technol 182:50-57. doi:10.1016/j.biortech.2015.01.065

Schäfer W, Lehto M, Teye F (2006) Dry anaerobic digestion of organic residues on-farm-a feasibility study. Agrifood Research Reports 77. MTT Agrifood Research Finland. 2006. www.mtt.fi/met/pdf/met77.pdf

Somayaji D, Khanna S (1994) Biomethanation of rice and wheat straw. World J Microbiol Biotechnol 10:521-523. doi:10.1007/ bf00367657

Sun GC, Wu YZ, Sha SJ, Liu KX (1987) Dry digestion of crop wastes: studies on dry anaerobic digestion with agricultural wastes. Biol Wastes 20:291-302

Sunarso S, Seno J, Widiasa IN (2012) The effect of feed to inoculums ratio on biogas production rate from cattle manure using rumen fluid as inoculums. Int J Waste Res 2:1-4

Zhou Y, Zhang Z, Nakamoto T, Li Y, Yang Y, Utsumi M, Sugiura N (2011) Influence of substrate-to-inoculum ratio on the batch anaerobic digestion of bean curd refuse-okara under mesophilic conditions. Biomass Bioenergy 35:3251-3256. doi:10.1016/j. biombioe.2011.04.002 